\title{
Regional Leste da ABPol Começa Bem Seu "Café com Polímeros"
}

Aliar o início de um dia de trabalho com um convidativo café da manhã pode ser uma opção bem interessante para quem não consegue mais sair da empresa depois que começou o expediente. Melhor ainda se o cafezinho for enriquecido com informações úteis. O sucesso do $1^{\circ}$ “Café com Polímeros" promovido pela Diretoria da Regional Leste da ABPol, dia 18 de maio último, no auditório do IMA/UFRJ, demonstrou que essa tese funciona.

Contando com o especial apoio do SIMPERJ, a Regional Leste ofereceu um saboroso café da manhã a cerca de 80 pessoas que lotaram o auditório do IMA para assistir à palestra do Dr. Roberto Villa. O Diretor Superintendente da Rio Polímeros, especialmente convidado, discorreu sobre o tema "Rio Polímeros - partida para o desenvolvimento?", abordando a opção pela tecnologia adotada na Rio Polímeros, dos passos do processo produtivo, sua escolha diferencial nos produtos comercializados no prémarketing. Roberto Villa comentou também o início da operação da planta no começo de 2005, com 540.000 toneladas/ano e os investimentos da Petroquisa divulgados pela Petrobrás para o setor.

Uma platéia atenta e diversificada, com representantes das indústrias de $3^{\text {a }}$ geração, profissionais de pesquisa e desenvolvimento, representantes do SENAI/FIRJAN, SEBRAE/RJ, profissionais de logística de empresas petroquímicas, alunos e professores, abrilhantou a apresentação com muitas perguntas, estendendo os debates além do previsto, inclusive durante o excelente café servido. A professora e mestra de todos, Prof ${ }^{a}$. Eloísa Mano, manifestava sua felicidade por rever tantos ex-alunos e, em especial, o palestrante, bastante elogiado pela qualidade das informações oferecidas.

Seguem, como ilustração, slides de alguns itens abordados durante a apresentação.

Vantagens competitivas (matérias-primas e mercado) e capacidade de produção de Polietilenos no Brasil.

\section{Vantagens Competitivas Matérias-primas}

- Utilização de Gás Natural:

$\checkmark$ Disponibilidade local;

$\checkmark$ Custo de Produção: comparação com nafta;

$\checkmark$ Menor investimento para geração de eteno.

- Bacia de Campos hoje e no futuro: o maior campo brasileiro de óleo e gás.

- Confiabilidade do fornecedor (Petrobras).

\author{
Vantagens Competitivas \\ Mercado \\ $\checkmark$ O volume global de vendas, em preços correntes, será da ordem de US\$ \\ 800 milhões/ano. \\ $\checkmark$ A Riopol abastecerá aproximadamente entre $18 \%$ e $20 \%$ do mercado \\ brasileiro, e exportará até $30 \%$ da sua produção. \\ $\checkmark$ A exportação será feita com contratos de longo prazo (Off-take), com \\ quantidades garantidas $(150.000 \mathrm{t} / \mathrm{a})$ nos 4 primeiros anos e $100.000 \mathrm{t} / \mathrm{a}$ nos \\ últimos 6 anos. \\ A \\ A Riopol será individualmente o maior exportador de polietilenos, e a partir \\ de 2007 , deverá responder por mais de $50 \%$ da exportação brasilei ra de \\ polietilenos.
}

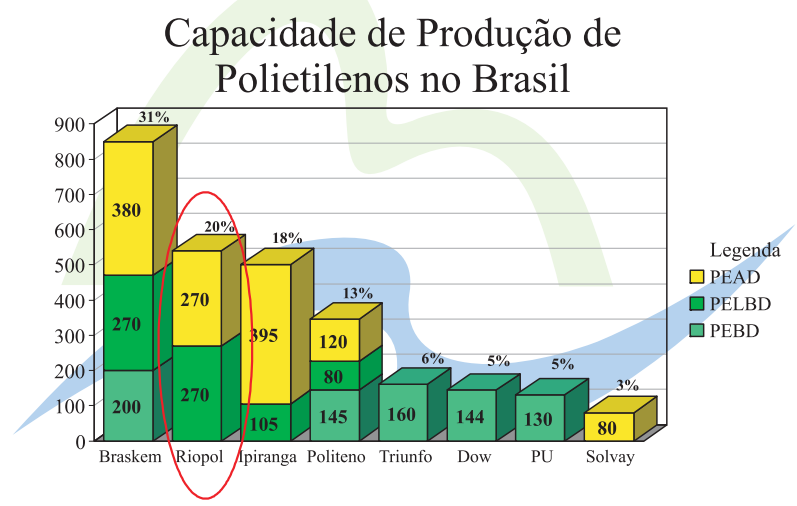

Antecipando o sucesso da iniciativa, Reinaldo W. Janke e a prof ${ }^{a}$. Elen Pacheco, diretor e vice-diretor da Regional Leste, respectivamente, já têm programado outros três "Café com Polímeros" ao longo do ano, com a participação de palestrantes abordando temas atuais como "Polietileno Verde", "Células Combustíveis" e "Refinaria: Pólo de pesquisa e desenvolvimento". Além desses encontros matinais, a Regional estará também promovendo no segundo semestre seu V Encontro da Regional Leste.

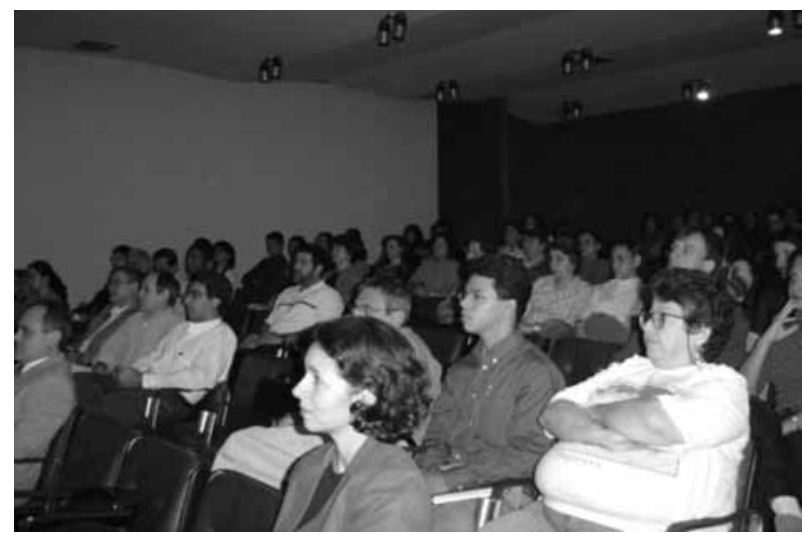

Vista parcial dos presentes 